\title{
Protective Effect of Vitamin C (Ascorbic Acid) Supplementation on Post-Thaw Motility and Fertility of Cryopreserved Rainbow Trout (Oncorhynchus mykiss) Sperm
}

\author{
Uğur Yavuz ${ }^{1, a}$, Yusuf Bozkurt ${ }^{2, b, *}$ \\ ${ }^{1}$ Graduate School of Natural and Applied Sciences, Mustafa Kemal University, 31000 Antakya/Hatay, Turkey \\ ${ }^{2}$ Faculty of Marine Sciences and Technology, Iskenderun Technical University, 31200 Iskenderun/Hatay, Turkey \\ *Corresponding author
}

A R T I C L E I N F O A B S T R A C T

Research Article

Received : 11/02/2020 Accepted : 28/04/2020

\section{Keywords:}

Cryopreservation

Oncorhynchus mykiss

Sperm

Vitamin C

Fertilization

Ascorbic acid (Vitamin C) is one of the important antioxidants, which naturally present in seminal plasma of fish. On the other hand, whether its effect may improve sperm quality following cryopreservation process still remains its uncertainty. Thus, the present study aimed to analyse the effect of different extenders supplemented with different ascorbic acid concentrations on post-thaw motility and fertility of frozen-thawed rainbow trout (Oncorhynchus mykiss) sperm. Selected sperm samples were pooled and diluted at 1:3 ratios with two different extenders (E) composing such as (E-1) $300 \mathrm{mM}$ glucose, 10\% egg yolk and 10\% DMSO and (E-2) $0.6 \mathrm{mM}$ sucrose and 10\% DMSO. Each extender was supplemented with vitamin $\mathrm{C}$ at 1,5 and $10 \mathrm{mM}$ concentrations. Following dilution, the sperm was loaded into $0.25 \mathrm{ml}$ straws and frozen in liquid nitrogen vapour. The straws were then plunged into liquid nitrogen for storage. Fertilization was carried out using the dry fertilization technique. Highest post-thaw motility $(50 \pm 5.77)$ and fertilization $(56 \pm 1.00)$ results were obtained with the extender-1 (E-1) containing 10\% DMSO concentration. In conclusion, the present study indicated that addition of ascorbic acid to the extenders improved rainbow trout sperm motility resulting higher fertilization of the eggs.

uguryavuz7676@hotmail.com

(D)https://orcid.org/0000-0002-8795-3562| b@yusuf.bozkurt@iste.edu.tr

http://orcid.org/0000-0002-6162-2466

\section{(c) 1 (i) (8) This work is licensed under Creative Commons Attribution 4.0 International License}

\section{Introduction}

Cryogenic preservation of sperm is an important biotechnological technique for providing of sperm without seasonal limitations, transporting of genetic material between locations and improving of selective breeding programmes in aquaculture. In addition, cryopreservation is considered as an important element to save endangered species via storing of gametes in gene banks.

Although cryopreservation is a valuable biotechnological technique, it can create mechanical and DNA damages and also change metabolism of sperm cells. On the other hand, the antioxidant capacity of sperm is inefficient to prevent these kinds of damages during the cryopreservation process. It is well known that the extenders supplemented with antioxidants lead to increasing of cell resistance against oxidative stress and improving of sperm quality (Yavaş et al., 2014).

Latest studies demonstrated that antioxidants could provide a powerful cryoprotective effect on sperm motility and membrane integrity in mammalians (Cabrita et al., 2011; Martinez-Paramo et al., 2012; Figueroa et al., 2015). On the other hand, the information on using of antioxidant supplemented estender is limited on rainbow trout sperm cryopreservation. From this point of view, Lahnsteiner et al. (2011) declared effect of antioxidant containing extenders are not clear in rainbow trout. Rainbow trout is the most dominant and cultured freshwater fish species providing a considerable portion of the food requirement of the world.

Ascorbic acid (vitamin C), is an important antioxidant, which naturally presents in seminal plasma of teleost fishes, originates from the diet and its concentration can be regulated by dietary treatment (Ciereszko and Dabrowski, 1995). Specifically, ascorbic acid prevents dissemination of chain reactions which triggered by free radicals. Also, it has the capability of prevention of lipid peroxidation and reducing of oxidative damage, which harmful for the membrane and DNA integrity in thawed spermatozoa (Cabrita et al., 2010).

From this point of view, there is limited information concerning how the addition of ascorbic acid effects motility and fertility of cryopreserved sperm. Therefore, the present study was designed to evaluate effect of ascorbic acid supplementations on ability of motility and fertility of cryopreserved rainbow trout sperm. 


\section{Material and Methods}

\section{Brood fish Care and Collection of Sperm}

Mature male and female rainbow trouts (Oncorhynchus mykiss) used in this study were 2 - 3 years old. They were provided by Kent Trout Aquafarm located in Karkamıs, Gaziantep, Turkey. During the experimental period, the brood fish was kept in $5 \mathrm{~m}^{3}$ net cages floating on the Karkamis dam lake with a mean temperature of $12.4 \pm 1.2^{\circ} \mathrm{C}$ and was maintained with a natural photoperiod. Brood fish was fed twice daily with commercial pelleted diet containing $35 \%$ protein.

Mature male and females were anesthetized in a clove oil bath $\left(50 \mu \mathrm{L}^{-1}\right)$ before stripping. Sperm was collected into falcon tubes by applying gentle abdominal massage and stored on ice until use. Eggs were collected from 5 females that had been stripped by gently massaging the abdomen. Eggs used in the experiments were well rounded and transparent.

\section{Evaluation of Sperm}

Evaluation of sperm was performed at $+4^{\circ} \mathrm{C}$ using a cold table. Sperm was used only if it is not contaminated by water, blood, urine or feces and motility more than $80 \%$. Sperm motility was activated with $0.3 \% \mathrm{NaCl}$ and evaluated using a phase contrast microscope (Olympus, Japan) at $400 \times$ magnification expressing as the percentage of cells with progressive motility. Samples below $80 \%$ motility were discarded. Movement duration of spermatozoa was assessed using a sensitive chronometer (sensitivity: 1/100 s) by recording the time following the addition of activation solution to the sperm samples.

In order to determine spermatozoa density, sperm was diluted at a ratio of 1:1.000 with Hayem solution (5 g $\mathrm{Na}_{2} \mathrm{SO}_{4}, 1 \mathrm{~g} \mathrm{NaCl}, 0.5 \mathrm{~g} \mathrm{HgCl}_{2}$ and $200 \mathrm{ml}$ bicine) and density was evaluated using a $100 \mu \mathrm{m}$ deep Thoma haemocytometer (TH-100; Hecht-Assistent, Sondheim, Germany) at 400x magnification with Olympus BX50 phase contrast microscope (Olympus, Japan) and expressed as spermatozoa $\times 10^{9} \mathrm{ml}^{-1}$ (three replicates). Sperm $\mathrm{pH}$ was measured using indicator papers (Merck). Following evaluation, selected sperm samples were pooled and stored at $+4^{\circ} \mathrm{C}$ until dilution and cryopreservation.

\section{Dilution of Sperm}

Pooled sperm was diluted at 1:3 ratio (semen/extender) of two different extenders. Extender 1 (E-1) contained 300 $\mathrm{mM}$ glucose, $10 \%$ egg yolk and $10 \%$ DMSO (Tekin et al. 2003) and Extender 2 (E-2) contained $0.6 \mathrm{mM}$ sucrose and 10\% DMSO (Conget et al. 1996). Each extender was supplemented with vitamin $\mathrm{C}$ (ascorbic acid) at 1, 5 and 10 $\mathrm{mM}$ concentrations.

\section{Cryopreservation and Thawing of Sperm}

The diluted sperm samples were drawn into 0.25-ml plastic straws (IMV, France) and sealed with polyvinyl alcohol (PVA). Having been diluted, the samples were equilibrated for $10 \mathrm{~min}$ at $4^{\circ} \mathrm{C}$. After equilibration, the straws were placed on a styrofoam rack floating on the surface of liquid nitrogen in a styrofoam box. The straws were frozen $3 \mathrm{~cm}$ above the surface of liquid nitrogen $\left(-120^{\circ} \mathrm{C}\right)$ for 10 min. Following freezing, the straws were plunged into the liquid nitrogen $\left(-196^{\circ} \mathrm{C}\right)$. For thawing, the straws were removed from liquid nitrogen and thawed at $30^{\circ} \mathrm{C}$ water bath for $25 \mathrm{~s}$. Thawed sperm was activated using $0.3 \%$ $\mathrm{NaCl}$ and observed under the microscope for the evaluation of spermatozoa motility.

\section{Fertilization}

Dry fertilization was applied in plastic dishes and approximately 250 eggs per batches were placed into each dish. Egg batches (three replicates per treatment) were fertilized with frozen or control semen (freshly collected). Sperm-to-egg ratio was approximately $3 \times 10^{6}$. Eggs and sperm were gently swirled for $10 \mathrm{~s}$ and then hatchery water was added to the sperm-egg mixture and left for $30 \mathrm{~min}$ to swell the eggs. After swelling, eggs were rinsed with hatchery water and each egg batches were placed into vertical incubation trays at the water temperature of $12 \pm 0.1^{\circ} \mathrm{C}$. Dead eggs were separated through regular siphoning during the incubation period and fertilization rates were calculated as the percentage at the eyed egg stage (150-160 degree-days) in each group.

\section{Statistical Analyses}

Results are presented as mean \pm S.D. and the differences between parameters were analyzed by repeated analysis of variance (ANOVA). Significant means were subjected to a multiple comparison test (Duncan) for post hoc comparison at a level of $\mathrm{P}<0.05$. Experiment was conducted as triplicate and all analyses were carried out using SPSS 10 for Windows statistical software package.

\section{Results}

The physical characteristics of fresh sperm (mean \pm S.D.) were summarized in Table 1. Effect of ascorbic acid concentrations on the post thaw motility rates of rainbow trout sperm were shown in Figure 1. The results of the present study indicated that differences in the motility rates of rainbow trout sperm were significant among the extenders $(\mathrm{P}<0.05)$. Highest mean motility rate $(50.00 \pm 5.77 \%)$ was at concentration of $10 \mathrm{mM}$ ascorbic acid group in extender-I. On the other hand, it was determined that there was no significant differences among the concentrations of ascorbic acid in extender-II.

Table 1. Fresh sperm quality parameters of rainbow trout brood fish $(n=12)$.

\begin{tabular}{l|cc}
\hline Parameters & Mean & Range \\
\hline Volume $(\mathrm{ml})$ & $8.9 \pm 3.14$ & $0.9-28$ \\
Motility $(\%)$ & $79.5 \pm 3.68$ & $60-95$ \\
Viability Period $(\mathrm{s})$ & $41.0 \pm 2.74$ & $25-55$ \\
Spz. Density $\left(\times 10^{9} \mathrm{ml}^{-1}\right)$ & $15.1 \pm 0.72$ & $11.9-18.7$ \\
Total Spz. Density $\left(\times 10^{9}\right)$ & $134.7 \pm 51.09$ & $14.3-523.6$ \\
pH & $7.0 \pm 0.00$ & - \\
Colour & Milky White & - \\
\hline
\end{tabular}

With regard to post-thaw fertility, differences in the fertilization rates of rainbow trout sperm were also significant among the extenders $(\mathrm{P}<0.05)$ (Figure 2$)$. Extender-I produced higher fertility results compared to extender-II. The overall mean fertilization rate was determined as $36.67 \pm 0.27$, while the mean highest fertilization rate was $56.00 \pm 1.00 \%$ when sperm cryopreserved with extender-I containing $10 \mathrm{mM}$ ascorbic 
acid. In spite of there were no significant differences $(\mathrm{P}>0.05)$ among the different ascorbic acid concentrations of extender- 1 , there were significant differences $(\mathrm{P}<0.05)$ in extender- 2 in terms of ascorbic acid concentrations.

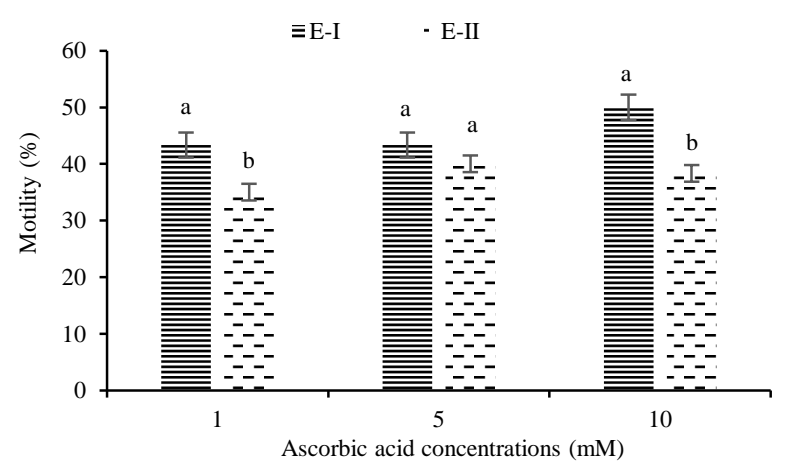

Figure 1. Effect of ascorbic acid on post-thaw motility of rainbow trout sperm $(n=3$; mean \pm S.E. $)$. Different letters indicate differences among datasets (ANOVA, $\mathrm{P}<0.05$ ).

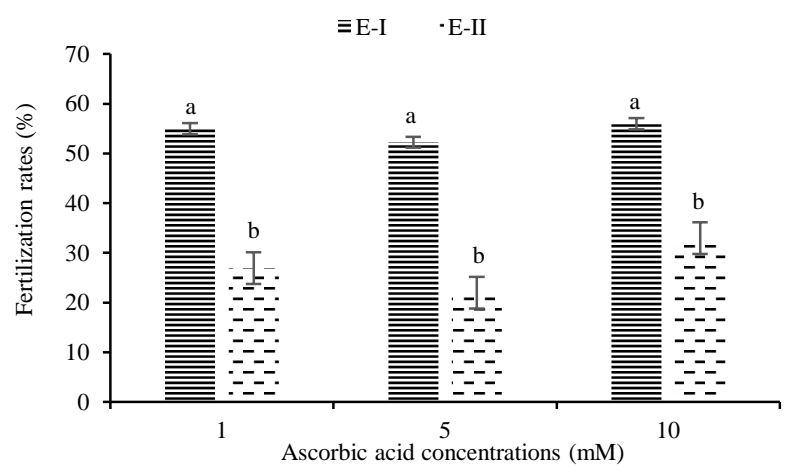

Figure 2. Effect of ascorbic acid on post-thaw fertility of rainbow trout sperm $(n=3 ;$ mean \pm S.E. $)$. Different letters indicate differences among datasets (ANOVA, $\mathrm{P}<0.05$ ).

\section{Discussion}

Cryopreservation is a valuable biotechnological application used for the conservation of aquatic genetic resources. This biotechnology also offers many benefits to aquaculture and as well as conservation of aquatic biodiversity. The benefits of this biotechnology includes year-round availability of gametes, reduction in need of keeping brood fish as alive in aquaculture facilities, preserving of valuable species and progress to genetic resource programmes (Bozkurt, 2018; Viveiros et al., 2012).

Cryopreservation success depends on not only conserving of spermatozoa motility but also maintaining of metabolic function (Watson, 2000). In general, the effect of cryopreservation process on spermatozoa is often explored in terms of motility, viability and fertilization capacity of sperm cells (Tekin et al., 2007). On the other hand, it is well known that the cryopreservation process promoting cell damages decreasing fertilization success, impairing of motility, membrane stability and spermatozoa functionality due to its oxidative damage (Y1ld1z, 2015).

Antioxidants are materials that restrict oxidation and prevent the production of free radicals as a result of oxidative stress mechanism. On the other hand, production of reactive oxygen species (ROS) leads to a decrease in the grade of antioxidants in seminal plasma. during the cryopreservation process. Thus, in spite of antioxidant defense system is active in seminal plasma of sperm, its activity in cell cytoplasm is constrained due to its low presence (Lahnsteiner and Mansour, 2010; Shiva et al., 2011). Several authors have exhibited that it is possible reducing of the destructive effect of ROS through the addition of antioxidants to the freezing media in several mammalian species (Michael et al., 2007; Thuwanut et al., 2008; Jeong et al., 2009). However, the effect of each antioxidant is species-specific because of improvement of different sperm quality parameters depending on type of molecule and concentration (Cabrita et al., 2011).

Vitamin $\mathrm{C}$ (ascorbic acid) is a natural antioxidant, which cleans radicals to remove free radical reactions (Martinez-Paramo et al., 2012). It has been demonstrated that the supplementation of ascorbic acid into the extenders reduces damaging effects of ROS and also develops the motility and viability of mammalian sperm (Askari et al., 1994; Michael et al., 2007; Thuwanut et al., 2008; Jeong et al., 2009). On the other hand, protective effects of ascorbic acid may vary among various animal species and there is lack of enough knowledge regarding its role and mechanisms in fish sperm.

Previous reports on mammalian, Yoshimoto et al. (2008) reported that an progress was observed in recovery and quality of frozen/thawed boar sperm when extender supplemented with ascorbic acid. Pena et al. (2003) reported positive effect of ascorbic acid supplementation on boar sperm motility, mitochondrial membrane and also membrane integrity. In teleost, Ubilla and Valdebenito (2011) declared that using of ascorbic acid in extenders improved motility and fertilizing capability of rainbow trout spermatozoa and also increased storage times of sperm cells as frozen state in liquid nitrogen. MartinezParamo et al. (2012) showed that complementation of extender with ascorbic acid improved sea bass (Dicentrarchus labrax) sperm motility. Mirzoyan et al. (2006) reported that extender combined with $10 \mathrm{mM}$ ascorbic acid increased Russian sturgeon (Acipenser gueldenstaedti) sperm motility rate as well as the reduction of chromosome aberrations in developing embryos.

The present results exhibited that each concentration of ascorbic acid in both extenders significantly provided better post-thaw sperm motility and fertility results. According to the experiments, $10 \mathrm{mM}$ ascorbic acid was the most effective concentration in order to obtain highest results in term of motility and fertilization in rainbow trout. This result is in line with those of the findings of Breininger et al. (2005) who reported that ascorbic acid acts as an antioxidant at high concentrations in boar sperm cryopreservation. Hu et al. (2010) and Beconi et al. (1993) reported $4.5 \mathrm{mg} / \mathrm{ml}$ and $5 \mathrm{mM}$ ascorbic acid as the best concentration in the extenders used for the cryoprotection of bovine sperm respectively. The useful effects of ascorbic acid can be grounded to the fact that being of its very efficient antioxidant and a remover of oxygen free radicals (Dawson et al. 1992).

On the other hand, Foote et al. (2002) determined that higher concentrations of ascorbic acid were harmful for the motility of cryopreserved bull semen. Cabrita et al. (2011) declared that supplementation of ascorbic acid did not significantly increase the post-thaw motility parameters of gilthead seabream (Sparus aurata). Studies in humans 
showed that low ascorbate concentrations $(0.02-0.6 \mathrm{mM})$ negatively affected sperm motility (Donnelly et al., 1999). Detrimental effect of vitamin $\mathrm{C}$ at $2.5 \mathrm{mM}$ concentrations was proven to sperm motility of cryopreserved bull semen (Beconi et al., 1993). Similar effects of ascorbic acid (1.5 $\mathrm{mM}$ ) were observed by Michael et al. (2007) for the canine sperm. However, Fernandez-Santos et al. (2007) reported no positive effect of ascorbic supplementation on postthaw sperm parameters in deer.

\section{Conclusion}

Based on the results from this study, the addition of ascorbic acid to the sugar based extenders improved frozen-thawed rainbow trout sperm motility and fertility. On the other hand, further studies are needed to determine and understand the certain physiological and protective roles of vitamin $\mathrm{E}$ and also vitamin $\mathrm{C}$ as antioxidants in cryopreservation of rainbow trout sperm.

\section{Acknowledgments}

The present study is a part of MSc. thesis and the authors would like to thank staff of the Kent Trout Aquafarm, in Gaziantep, Turkey.

\section{References}

Askari HA, Check JH, Peymer N, Bollendorf A. 1994. Effect of natural antioxidants tocopherol and ascorbic acids in maintenance of sperm activity during freeze-thaw process. Archieves of Androl., 33:11-15. DOI: 10.3109/01485019408987797.

Beconi MT, Francia CR, Mora NG, Affranchino MA. 1993. Effect of natural antioxidants on frozen bovine semen preservation. Therio., 40:841-851. DOI: 10.1016/0093691X(93)90219-U.

Bozkurt Y. 2018. Introductory chapter: Application Fields of Cryopreservation Biotechnology - In: Cryopreservation Biotechnology in Biomedical and Biological Sciences. Bozkurt, Y. (Ed.). Section I, p. 1-4. IntechOpen Publications, London, United Kingdom. ISBN:978-1-78984-681-2.

Breininger E, Beorlegui NM, O'Flaherty CM, Beconi MT. 2005. Alpha -tocopherol improves biochemical and dynamic parameters in cryopreserved boar semen. Therio., 63: 21262135. DOI: 10.1016/j.theriogenology.2004.08.016.

Cabrita E, Sarasquete C, Martinez-Páramo S, Robles V, Beirão J, Pérez-Cerezales S, Herráez MP. 2010. Cryopreservation of fish sperm: applications and perspectives. J. Appl. Ichthyol., 26: 623-635. DOI: 10.1111/j.1439-0426.2010.01556.x.

Cabrita E, Ma S, Diogo P, Martinez-Paramo S, Sarasquete S, Dinis MT. 2011. The influence of certain aminoacids and vitamins on frozen-thawed fish sperm motility, viability and DNA fragmentation. Anim. Reprod. Sci., 125(1):189-195. DOI: 10.1016/j.anireprosci.2011.03.003.

Ciereszko A, Dabrowski K. 1995. Sperm quality and ascorbic acid concentration in rainbow trout semen are affected by dietary vitamin C: An across-season study. Biol. Reprod., 52: 982-988. DOI: 10.1095/biolreprod52.5.982.

Conget P, Fernandez M, Herrera G, Minguell J. 1996. Cryopreservation of rainbow trout spermatozoa using programmable freezing. Aquacult., 143:319-329. DOI: $10.1016 / j$.aquaculture.2013.11.014.

Dawson EB, Harris WA, Teter MC. 1992. Effect of ascorbic acid supplementation on the sperm quality of smokers. Fertil. Steril., 58: 1034-1039. DOI: 10.1016/S0015-0282(16)554569.
Donnelly ET, McClure N, Lewis SEM. 1999. Antioxidant supplementation in vitro does not improve human sperm motility. Fertil. Steril., 72: 484-495. DOI: 10.1016/S00150282(16)55456-9.

Fernandez-Santos MR, Martinez-Pastor F, Garcia-Macias V, Esteso MC, Soler AJ, Paz P, Anel L, Garde JJ. 2007. Sperm characteristics and DNA integrity of Iberian red deer (Cervus elaphus hispanicus) epididymal spermatozoa frozen in the presence of enzymatic and non-enzymatic antioxidants. J. Androl., 28: 294-305. DOI: 10.2164/jandrol.106.000935.

Figueroa E, Merino O, Risopatron J, Isachenko V, Sanchez R, Effer B, Isachenko E, Farias JG, Valdebenito I. 2015. Effect of seminal plasma on Atlantic salmon (Salmo salar) sperm vitrification. Therio., 83: 238-245. DOI: 10.1016 /j.theriogenology.2014.09.015.

Foote RH, Brockett CC, Kaproth MT. 2002. Motility and fertility of bull sperm in whole milk extenders containing antioxidants. Anim. Reprod. Sci., 71: 13-23. DOI: 10.1016/S0378-4320(02)00018-0.

Hu JH, Zan LS, Zhao XL, Li QW, Jiang ZL, Li YK, Li X. 2010. Effects of trehalose supplementation on semen quality and oxidative stress variables in frozen-thawed bovine semen. J. Anim. Sci., 88: 1657-1662. DOI: 10.2527/jas.2009-2335.

Jeong YJ, Kim MK, Song HJ, Kang EJ, Ock SA, Mohana KB, Balasubramanian S, Rho GJ. 2009. Effect of alpha-tocopherol supplementation during boar semen cryopreservation on sperm characteristics and expression of apoptosis related genes. Cryobiol., 58: 181-189. DOI: 10.1016 /j.cryobiol.2008.12.004.

Lahnsteiner F, Mansour N, Kunz FA. 2011. The effect of antioxidants on the quality of cryopreserved semen in two salmonid fish, the brook trout (Salvelinus fontinalis) and the rainbow trout (Oncorhynchus mykiss). Therio., 76: 882-890. DOI: 10.1016/j.theriogenology.2011.04.019.

Lahnsteiner F, Mansour NA. 2010. A comparative study on antioxidant systems in semen of species of the Percidae, Salmonidae, Cyprinidae and Lotidae for improving semen storage techniques. Aquacult., 307: 130-140. DOI: 10.1016/j.aquaculture.2010.07.011.

Martinez-Paramo S, Diogo P, Dinis MT, Herraez MP, Sarasquete C, Cabrita E. 2012. Incorporation of ascorbic acid and atocopherol to the extender media to enhance antioxidant system of cryopreserved seabass sperm. Therio., 77: 11291136. DOI: 10.1016/j.theriogenology.2011.10.017.

Michael A, Alexopoulos C, Pontiki E, Hadjipavlou-Litina D, Saratsis P, Boscos C. 2007. Effect of antioxidant supplementation on semen quality and reactive oxygen species of frozen-thawed canine spermatozoa. Therio., 68: 204-212. DOI: 10.1016/j.theriogenology.2007.04.053.

Mirzoyan AV, Nebesikhina NA, Voynova NV, Chistyakov V.A. 2006. Preliminary results on ascorbic acid and lysine suppression of clastogenic effect of deep-frozen sperm of the Russian sturgeon (Acipenser gueldenstaedti). Int. J. Refrigerat., 29: 374-378. DOI: 10.1016/j.jirefrig. 2005.07.008.

Pena FJ, Johansson A, Wallgren M, Rodriguez MH. 2003. Antioxidant supplementation in vitro improves boar sperm motility and mitochondrial membrane potential after cryopreservation of different fractions of the ejaculate. Anim. Reprod. Sci.,78:85-98. DOI: 10.1016/S0378-4320(03)000496.

Shiva M, Gautam AK, Verma Y, Shivgotra V, Doshi H, Kumar S. 2011. Association between sperm quality, oxidative stress, and seminal antioxidant activity. Clin. Biochem., 44: 319324. DOI: 10.1016/j.clinbiochem.2010.11.009.

Tekin N, Seçer S, Akcay E, Bozkurt Y, Kayam S. 2007. Effects of glycerol additions on post-thaw fertility of frozen rainbow trout sperm, with an emphasis on interaction between extender and cryoprotectant. J. Appl. Ichthyol., 23(1): 60-63. DOI: 10.1111/j.1439-0426.2006.00792.x. 
Tekin N, Seçer S, Akçay E, Bozkurt Y. 2003. Cryopreservation of rainbow trout (Oncorhynchus mykiss) semen. Isr. J. Aquacult-Bamid., $\quad 55 \quad$ (3): $208-212$ Available from: http://hdl.handle.net/10524/19084. Accessed: 08.02.2020.

Thuwanut P, Chatdarong K, Techakumphu M, Axnér E. 2008. The effect of antioxidants on motility, viability, acrosome integrity and DNA integrity of frozen-thawed epididymal cat spermatozoa. Therio., 70: 233-240. DOI: 10.1016/j.theriogenology.2008.04.005.

Ubilla A, Valdebenito I. 2011. Use of antioxidants on rainbow trout Oncorhynchus mykiss (Walbaum, 1792) sperm diluent: effects on motility and fertilizing capability. Lat. Am. J. Aquat. Res., 39: 338-343. DOI: 10.4067/S0718560X2011000200015.

Viveiros ATM, Isaú ZA, Caneppele D, Leal, MC. 2012. Sperm cryopreservation affects postthaw motility, but not embryogenesis or larval growth in the Brazilian fish Brycon insignis (Characiformes). Therio., 78:803-810. DOI:10.1016/j.theriogenology.2012.03.028.
Watson PF. 2000. The causes of reduce fertility with cryopreserved semen. Anim. Reprod., Sci. 60-61:481-492. DOI: 10.1016/S0378-4320(00)00099-3.

Yavaş I, Bozkurt Y, Yıldız C. 2014. Cryopreservation of scaly carp (Cyprinus carpio) sperm: effect of different cryoprotectant concentrations on post-thaw motility, fertilization and hatching success of embryos. Aquacult. Int., 22: 141-148. DOI: 10.1007/s10499-013-9698-6.

Yıldız C, Yavaş I, Bozkurt Y, Aksoy M. 2015. Effect of cholesterol-loaded cyclodextrin on cryosurvival and fertility of cryopreserved carp (Cyprinus carpio) sperm. Cryobiol., 70(2):190-194. DOI: 10.1016/j.cryobiol.2015.01.009.

Yoshimoto S, Okada E, Umemoto H, Tamura K, Uno $\mathrm{Y}$, Nishikida UC, Matsuda Y, Takamatsu N, Shiba T, Ito M. 2008. AW-linked DM-domain gene, DM-W, participates in primary ovary development in Xenopuslaevis. Proc. Natl. Acad. Sci. USA 105: 2469-2474. DOI: 10.1073/pnas.0712244105. 